\title{
EFFECT OF SALT TREATMENT ON YIELD AND QUALITY OF FROZEN COD LOINS
}

\author{
Viktoras Liorančas \\ Klaipèda State University of Applied Sciences, Lithuania \\ v.liorancas@kvk.1t
}

\begin{abstract}
Study has been performed in fish processing plant ' $\mathrm{X}$ ' with an aim of on purpose to investigating the influence of salt treatment on yield and quality of frozen cod loins. Samples were soaked in $0.8,1.2,10 \% \mathrm{NaCl}$ concentrations in brine before being frozen. In this study, the cod loin's weight loss during refrigeration, defrosting and cooking was calculated and sensory analysis was carried out. It was found that the soaking in brines affected higher weight of cod loins after freezing. In the control group it decreased by $1.14 \%$, but the S0.8, S1.2 and S10 groups had the weight gain, respectively $3.41,4.72$ and $+4.78 \%$. Although after the defrosting and cooking the control group had the lowest weight losses, considering the losses of all operations, it was found that the largest weight loss was in the control group and in the S0.8 group, respectively $31.19 \%$ and $31.29 \%$, while the lowest in the S1.2 and S10 groups - 30.49 and $30.06 \%(p<0.05)$, respectively. Salt treatment did not affect the taste and odor, but improved the cod loin's texture properties. Based on these results, salt treatment is considered as an effective way to improve the yield and quality of frozen cod loins.
\end{abstract}

Key words: cod, salt treatment, production yields, sensory properties.

\section{Introduction}

One of the most important factors in improving food safety and competitiveness is its quality and stability. Consumers are interested in the ability of each company to organize their activities in order to market high quality products. Food quality is characterized by nutritional, physiological, safety and energy values. Modern food quality is not only nutritional and energy value, but also food safety.

The quality of fish meat is influenced by various factors: fish species, physiological state, catch method, processing technology and etc. (Andriejauskienè \& Liorančas, 2011). The market is demanding meat, which is characterized by acceptable sensory properties, technological and culinary characteristics. In many European countries, the meat market is overcrowded, and various ways of improving its quality and competitiveness are sought (Jukna, Jukna, \& Šimkus, 2003). High quality raw material enables processors to produce high quality and competitive fish products. Fish processing occupies an important place among other factors affecting quality. The final quality of the fish product will depend on how the refrigeration, freezing and other processing processes are carried out (Čiulevičius, 1987).

Whole fish with a protective coating (scales, skin) will stay much longer under the same conditions than fillets. Additional protection is required to protect the fillet and improve its technological properties. Freezing is one of the most employed methods used for preserving fresh fish and seafood products. However, in the frozen state of fish, physical, chemical and enzymatic changes are able to appear eventually rendering the tissue to an undesirable state (Abraha et al., 2018). Pourshamsian, Ghomi \& Nikoo (2012) reported that taste, color and texture are some of the quality deterioration factors that occur in food during frozen storage. Freezing rate, thawing methods, and temperature fluctuations are main factors which affect the extent of fish product quality loss. Freezing maintains the product fresh and extends shelf life for a long time. This depends on several factors, such as initial condition of fish and time elapsed between harvest and freezing. These factors can influence protein denaturation and texture defect can occur (Yerlikaya \& Gokoglu, 2010). In frozen fish process protein denaturation might occur. Once protein is denatured, muscle texture, water holding capacity, color and flavor of frozen fish and fish products are affected, since muscle protein is the main contributor to the characteristic textural properties (Sriket, Benjakul, \& Visessanguan, 2017).

Nowadays, the interest in brine's ability to improve the quality of whole muscle beef, pork and poultry products is increasing (Harikedua \& Mireles DeWitt, 2017). During the salt treatment, a thin layer of denaturated proteins is obtained on the surface of the fillet, which protects it from the external factors, reduces drying during freezing and weight loss during defrosting (Valtýsdóttir et al., 2010, 2011). Low brine concentration typically has less than $5 \% \mathrm{NaCl}$ and is used just to impact muscle protein functionality without altering flavor/appearance. Low brine concentration also reduces drip loss during storage and cooking-loss, improves juiciness and extends shelf life by inhibiting bacterial activity (Robbins et al., 2002; Parsons et al., 2011; Sen et al., 2005; Rowe et al., 2009). Low concentration saline brines do not stop, but only slow down microbial activity (U.S. Department of Health and Human Services, 2011). Slight treatment with salt has a positive effect on the activity of enzymes in meat (transglutaminase, etc.). Salt releases water, which is later used to form the texture of fish meat (Ramirez et $a l ., 2002)$. Qiancheng (2008) argues that the quality 
of fish fillets can be improved by salt treatment. This improves water-binding and sensory properties. Thus, the aim of this study was to investigate the influence of salt treatment on yield and quality of frozen cod loins.

\section{Materials and Methods}

The study was performed in the fish processing plant ' $\mathrm{X}$ ' which is specializing in the processing of fresh and frozen Atlantic cod (Gadus Morhua) from the North Sea. Above-mentioned company meets all hygiene, sanitary and environmental requirements. For this study cod loins were cut from the middle section of fattest part of the fillet. The loin size ranged from 75 to $90 \mathrm{~g}$. Four research groups of 15 samples each were used for the study. The control group were cod loins without treatment. The second group (S0.8) soaked in $0.8 \% \mathrm{NaCl}$ solution $(1 \mathrm{~h} 30$ $\mathrm{min})$; the third group (S1.2) soaked in $1.2 \% \mathrm{NaCl}$ solution (1 h $30 \mathrm{~min}$ ); the fourth group (S10) soaked in $10 \% \mathrm{NaCl}$ solution $(5 \mathrm{~min})$. The treatment was done in ice-water baths at tempetrature of $+1{ }^{\circ} \mathrm{C}$ and afterwards all loins were frozen, packed in cartons lined with plastic bag and stored for one week at $-20{ }^{\circ} \mathrm{C}$. Throughout the test, control of the weight of the cod loins was performed to determine weight loss during freezing, dry defrosting and cooking. Defrosting loss was determined by the weight loss of the sample over 24 hours holding it in special bags of mesh at $+4{ }^{\circ} \mathrm{C}$ (Honikel, 1998). The salt content in defrosted loins was determined by Mohr method. The cooking loss was determined by Shilling's (1966) method of weighing the loin sample before cooking and after. Cooking was done in a circulating water bath for $30 \mathrm{~min}$ at $70{ }^{\circ} \mathrm{C}$ (Howgate, 2010). After this heat treatment, the sensory analysis of the products was performed according to the requirements of LST ISO 8589:2010 and sensory profiles were established. Samples were evaluated according to taste, smell and texture (Table 1). The intensity of each property of the product was evaluated and from these data, a mathematical statistical profile was used to form a profile of the sensory characteristics of each product. A group of 6 assessors participated in the sensory proficiency test. The assessors were selected and trained to work in accordance with LST ISO 8586-1.

\section{Results and Discussion}

The study results revealed that salt concentration did not exceed $1 \%$ (Table 2). Naturally, the salt content in cod meat ranges from 0.4 to $0.9 \%$, because cod lives in salty waters, so it already has a slight amount of salt. (Waterman, 2001; Esaiassen et al., 2004; Roe et $a l ., 2013)$. However, we can see that the control group had the lowest amount of salt $(0.19 \%)$.

Normal weight loss during freezing is up to $2.5 \%$ for fish and other seafood (Johnston et al., 1994) and during defrosting in open air - up to 5\% (Archer, Edmonds, \& George, 2008). As it can be seen from the results of the study in Table 3 , the weight of cod loins

\section{Sensory properties and descriptions}

Table 1

\begin{tabular}{|l|l|l|}
\hline \multicolumn{1}{|c|}{ Properties } & \multicolumn{1}{c|}{ Scale } & \multicolumn{1}{c|}{ Description } \\
\hline Total odor intensity & Low - intense & Intensity of general smell \\
\hline Cooked fish smell & Low - intense & Intensity of smell characteristics of cooked loins \\
\hline Hardness & Low - high & Feature defining the force needed to bite the sample \\
\hline Fibrousness & Low - high & $\begin{array}{l}\text { Evaluation of individual fibers in the sample which are felt } \\
\text { while chewing }\end{array}$ \\
\hline Chewingness & Low - high & Number of bites and / or duration required to chew bite \\
\hline Juiciness & Low - high & The product's ability to extract juice by chewing \\
\hline Total flavor intensity & Low - high & Intensity of general sense of taste \\
\hline Intensity of cooked fish flavor & Low - high & Intensity of cooked fish flavor \\
\hline Saltiness & Low - high & Intensity of the salty sense \\
\hline
\end{tabular}

Statistical analysis of results was performed using SPSS statistical software, version 20.0.

\section{Concentrations of $\mathrm{NaCl}$ in cod loins}

\begin{tabular}{|c|c|}
\hline Groups & $\mathrm{NaCl} \%$ \\
\hline Control & $0.19 \pm 0.05$ \\
\hline S0.8 & $0.29 \pm 0.06$ \\
\hline S1.2 & $0.61 \pm 0.08$ \\
\hline S10 & $0.70 \pm 0.07$ \\
\hline
\end{tabular}

Data on weight loss during refrigeration, defrosting and cooking are presented in Table 3. 
Production yields during technological processes (g)

\begin{tabular}{|c|c|c|c|c|c|c|}
\hline \multirow[b]{2}{*}{ Sample } & \multicolumn{6}{|c|}{ Technological processes } \\
\hline & $\begin{array}{c}\text { Before salt } \\
\text { treatment /before } \\
\text { freezing }\end{array}$ & $\begin{array}{c}\text { After salt } \\
\text { treatment /after } \\
\text { freezing }\end{array}$ & $\begin{array}{c}\text { Before } \\
\text { defrosting }\end{array}$ & $\begin{array}{c}\text { After } \\
\text { defrosting }\end{array}$ & $\begin{array}{l}\text { Before } \\
\text { cooking }\end{array}$ & $\begin{array}{c}\text { After } \\
\text { cooking }\end{array}$ \\
\hline Control & 87.67 & 86.67 & 85.80 & 79.32 & 79.32 & 61.47 \\
\hline Yields (\%) & \multicolumn{2}{|c|}{$-1.14 \%$} & \multicolumn{2}{|c|}{$-7.55 \%$} & \multicolumn{2}{|c|}{$-22.50 \%$} \\
\hline S0.8 & 78.33 & 81.00 & 80.09 & 71.93 & 71.93 & 54.30 \\
\hline Yields (\%) & \multicolumn{2}{|c|}{$+3.41 \%$} & \multicolumn{2}{|c|}{$-10.19 \%$} & \multicolumn{2}{|c|}{$-24.51 \%$} \\
\hline S1.2 & 84.67 & 88.67 & 87.06 & 77.42 & 77.42 & 58.73 \\
\hline Yields (\%) & \multicolumn{2}{|c|}{$+4.72 \%$} & \multicolumn{2}{|c|}{$-11.07 \%$} & \multicolumn{2}{|c|}{$-24.14 \%$} \\
\hline $\mathrm{S} 10$ & 83.67 & 87.67 & 86.75 & 79.46 & 79.46 & 58.45 \\
\hline Yields (\%) & \multicolumn{2}{|c|}{$+4.78 \%$} & \multicolumn{2}{|c|}{$-8.40 \%$} & \multicolumn{2}{|c|}{$-26.44 \%$} \\
\hline
\end{tabular}

in the control group decreased by $1.14 \%(\mathrm{p}<0.05)$ after freezing. The S0.8, S1.2 and S10 groups had the largest weight gains $-3.41,4.72$ and $+4.78 \%$ $(p<0.05)$, respectively.

After defrosting, the weight loss of all groups exceeded 5\%, although the control group had the lowest weight loss during defrosting, which was $7.55 \%(\mathrm{p}<0.05)$.

After cooking, the smallest weight loss was in the control and the highest in the S10 group because treated loins had less weight losses in previous processes, so this means that if there is more moisture in the fish, the loss during cooking is higher.

Taking into account the weight loss of all groups (Figure 1), all technological processes show that the largest weight loss was in the control group and in the S0.8 group $-31.19 \%$ and $31.29 \%$, respectively, while the lowest in the S1.2 and S10 group - 30.49 and $30.06 \%(p<0.05)$, respectively.

For the sensory analysis, the samples were grouped into control and treated groups. There were no significant differences between the groups in the sensory profiles of the smell and taste (Figure 2) in this study.

As regards the sensory profiles of the texture (Figure 3), it was found that hardness, fibrousness and chewiness were most pronounced in the control group $(\mathrm{p}<0.05)$. Based on the results of the sensory evaluation, we found that soaking in salt brines had a positive effect on the sample properties. The best sensory profiles were in the S1.2 and S10 study groups: they were more tender, less fibrous, with better chewiness and more juicy $(\mathrm{p}<0.05)$.

In this study, the salt treatment increased higher yields and sensory quality. Esaiassenet et al. (2004) got similar results and found that the intensity of the attributes - cod smell, cod taste, glossiness, juiciness, flakiness and whiteness - were higher in the brined products compared with non-brined. Later Esaiassene, Østli \& Joensen (2005) studied the effect of phosphate, salt, glucose, ascorbate and starch on yield, sensory quality and consumers liking,

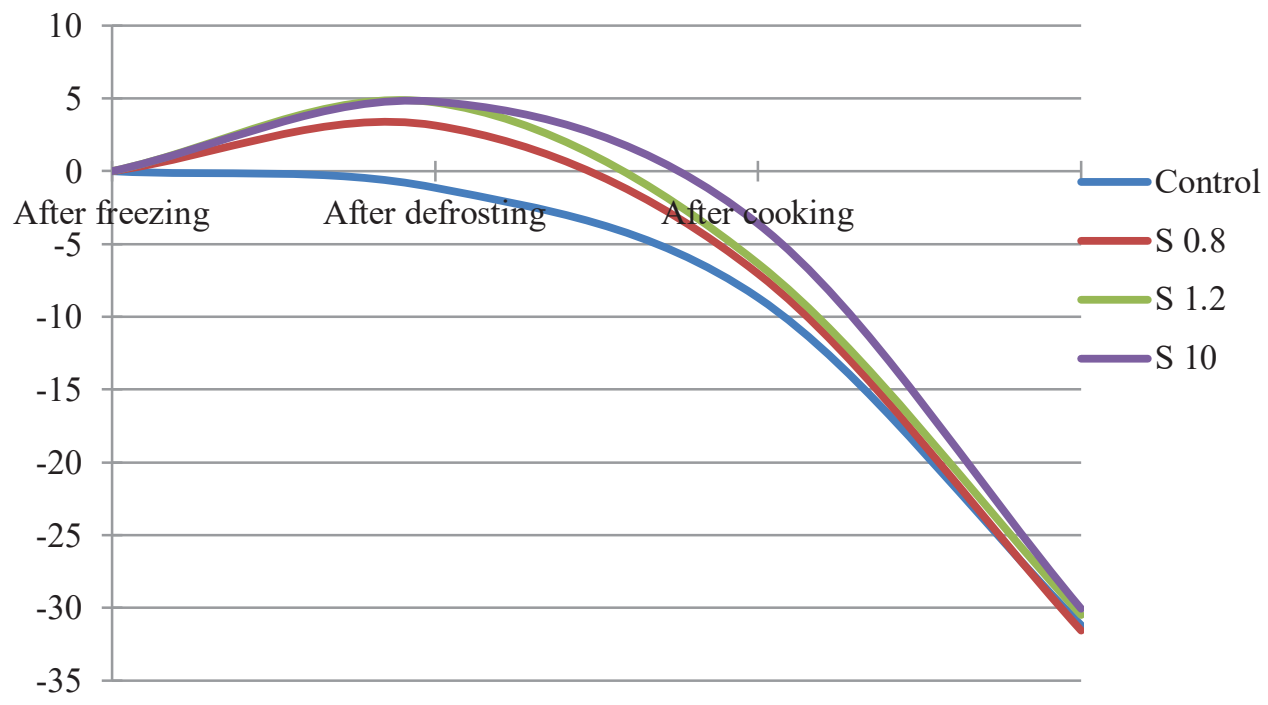

Figure 1. Total weight loss during cod's processing, $\%$. 


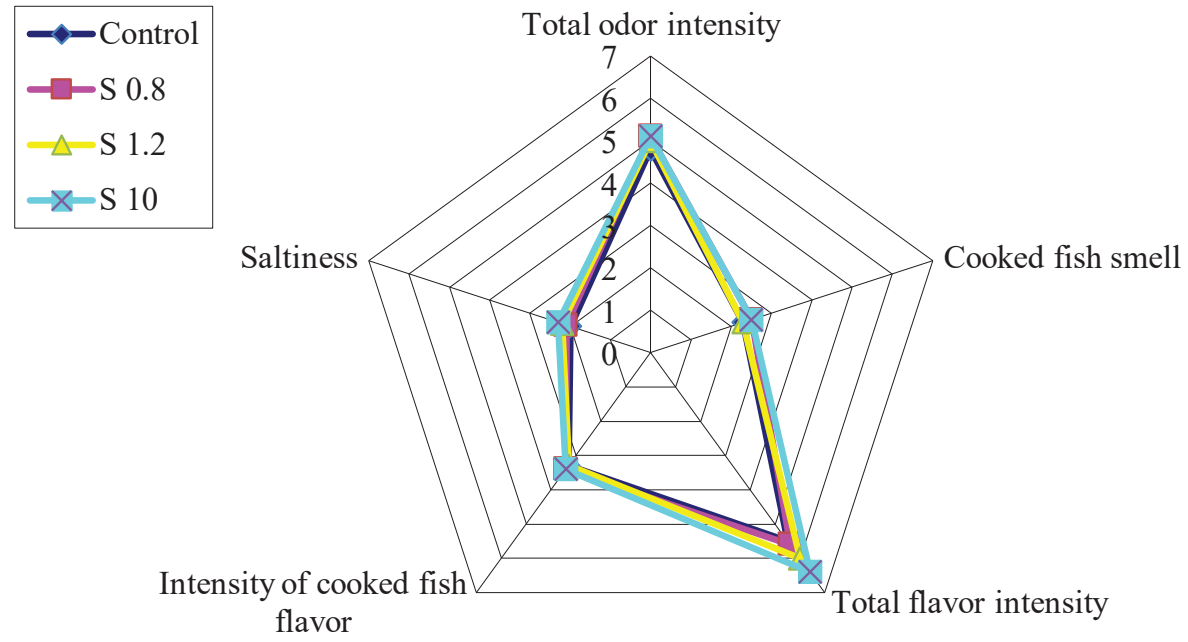

Figure 2. Smell and flavor sensory profile.
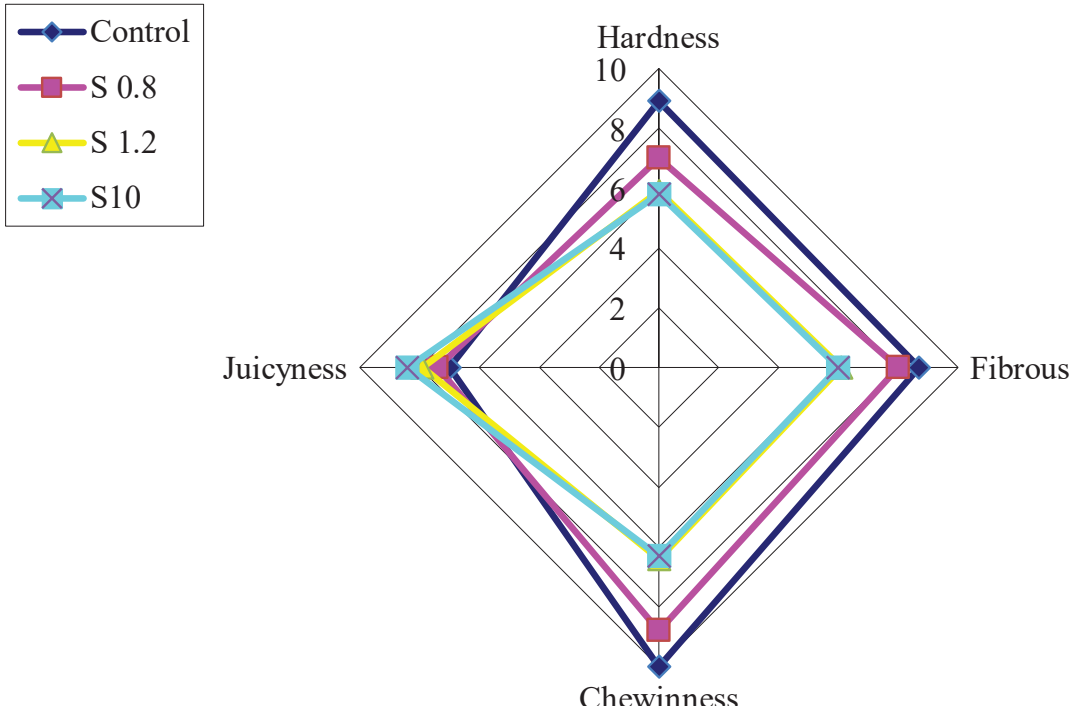

Figure 3. Sensory texture's profile.

and found that salt was the variable with the highest pronounced effect on yield, followed by triphosphate, glucose, starch and sodium ascorbate. Consequently, sensory analyses showed that the intensity of the sensory attributes - cod taste, cod smell, juiciness, whiteness and glossiness - could be heightened by brining, while the intensities of old/stale taste and smell could be lowered. However, there are other ways of increasing yield and quality but they use salt injections with additives, which obtain different results. Qiancheng's (2008) study showed that a combination of fresh protein isolate with salt injected into saithe and kept frozen resulted in lower cooking losses than only a salt injection. Thus, Thorarinsdottir et al. (2004) found that injection with salt had higher cooking yield compared to the mixture of protein and salt injection into cod fillets, which were kept frozen. These differences might occur because different salt concentrations were used in studies mentioned above.
Summarizing, it is clear that brining considerably enhances the yields and sensory properties of frozen and thawed cod fillets.

\section{Conclusions}

Based on the results of the research, it can be stated that salt treatment at the time of refrigeration increases the yield in range of 3.41 to $4.78 \%$.

Although the weight loss of the study groups is higher during defrosting and cooking, however, the data obtained from all technological processes indicate that soaking cod loins in salt brines reduces the total weight loss during freezing, thawing and cooking.

Soaking in low concentration brine does not affect the taste and smell but improves the texture of the samples.

Therefore, the salt treatment for cod loin is an effective way to improve its weight and sensory quality. 


\section{References}

1. Abraha, B., Admassu, H., Mahmud, A., Tsighe, N., \& Shui, X.W. (2018). Effect of processing methods on nutritional and physico-chemical composition of fish: a review. MOJ Food Processing \& Technology; 6(4), 376-382.

2. Andriejauskienè, J., \& Liorančas, V. (2011). Žuvininkystès pagrindai ir žuvų ligos (Basic of Fisheries and Fish diseases). Klaipèda, Klaipèda University. 61-62. (in Lithuanian)

3. Archer, M., Edmonds, M., \& George, M. (2008). Thawing seafood. Swedish Research \& Development Department. Retrieved March 10, 2019, from https://www.seafish.org/media/Publications/SR598_ Thawing.pdf.

4. Čiulevičius, J. (1987). Gyvulininkystès produktu kokybès efektyvumas (Efficiency of livestock products quality). Vilnius. 91. (in Lithuanian)

5. Esaiassen, M., Edel, J., Joensen, O., Richardsen, R., \& Prytz, K. (2004). Brining of cod fillets: influence on sensory properties and consumers liking. Food Quality and Preference. 15 (5), 421-428.

6. Esaiassen, M., Østli J., \& Joensen, S. (2005). Brining of cod fillets: effects of phosphate, salt, glucose, ascorbate and starch on yield, sensory quality and consumers liking. Food Science and Technology. 38(6), 641-649.

7. Harikedua, S.D., \& Mireles DeWitt, C. (2017). Preventing Soft Texture Fish Fillets through Brine Injection. Journal of Food Quality. Article ID 1875872. 7 p. DOI: 10.1155/2017/1875872.

8. Honikel, K. (1998). Reference Methods for the Assessment of Physical in Meat. Meat science. 49(4).

9. Howgate, P. (2010). Selection and Training of Assessors for Sensory Evaluation of Fish. Retrieved March 02, 2019, from http://seafood.oregonstate.edu/.pdfproc.20Links/selection-and-training-of-assessors.pdf.

10. Johnston, W.A., Nicholson, F.J., Roger, A., \& Stroud, G.D. (1994). Freezing and refrigerated storage in fisheries. Food and Agriculture Organization of the United Nations. Rome. Retrieved March 03, 2019, from http://www.fao.org/3/V3630E/V3630E00.htm.

11. Jukna, Č., Jukna, V., \& Šimkus, A. (2003). Mineralinių medžiagų ir vitaminų įtaka mėsos fizinèms savybèms (Influence of mineral substances and vitamins on physical properties of meat). Veterinarija ir zootechnika. T. 23 (45), 74-78. (in Lithuanian)

12. Parsons, A.N., Van Overbeke, D.L., \& Goad, C.L., DeWitt, C.A.M. (2011). Retail display evaluation of steaks from select beef strip loins injected with a brine containing $1 \%$ ammonium hydroxide. Part 2: cook yield, tenderness, and sensory attributes. Journal of Food Science, 76 (1), 84-88.

13. Pourshamsian, K., Ghomi, M., \& Nikoo, M. (2012). Fatty Acid and Proximate Composition of Farmed Great Sturgeon (Huso huso) Affected by Thawing Methods, Frying Oils and Chill Storage. Advanced Studies in Biology. 4(2), 67-76.

14. Qiancheng, Z. (2008). Effects of salt and protein injection on yield and quality changes during storage of chilled and frozen saithe fillets. Final Project. Fisheries training programme, Iceland. Retrieved March 10, 2019, from http://www.unuftp.is/static/fellows/document/zhao_2008prf.pdf.

15. Ramírez, J., Uresti, R., Téllez, S., \& Vázquez, L. (2002). Using salt and microbial transglutaminase as binding agents in restructured fish products resembling hams. Journal of Food Science. 67, 1778-1784.

16. Robbins, K., Jensen J., Ryan, K.J., Homco-Ryan, C., McKeith, F.K., \& Brewer, M.S. (2002). Enhancement effects on sensory and retail display characteristics of beef rounds. Journal of Muscle Foods, 13 (4), 279288.

17. Roe, M., Church, S., Pinchen, H., \& Finglas, P. (2013). Nutrient Analysis of Fish and Fish Products. Institute of Food Research, UK. 19.

18. Rowe, C.W., Pohlman, F.W., Brown, A.H. Jr., Johnson, Z.B., Whiting, S.H., \& Galloway, D.L. (2009). Effects of conjugated linoleic acid, salt, and sodium tripolyphosphate on physical, sensory, and instrumental color characteristics of beef striploins. Journal of Food Science, 74 (1), 36-43.

19. Sen, A.R., Naveena, B.M., Muthukumar, M., Babji, Y., \& Murthy, T.R.K. (2005). Effect of chilling, polyphosphate and bicarbonate on quality characteristics of broiler breast meat. British Poultry Science, 46 (4), 451-456.

20. Sriket, P., Benjakul, S., \& Visessanguan, W. (2007). Comparative studies on the effect of the freezethawing process on the physicochemical properties and microstructures of black tiger shrimp (Penaeus monodon) and white shrimp (Penaeus vannamei) muscle. Food Chemistry, 104(1), 113-121.

21. Thorarinsdottir, K.A., Gunmundsdottir, G., Arason, S., Thorkelsson, G., \& Kristbergsson, K. (2004). Effects of added Salt, phosphates, and proteins on the chemical and physicochemical characteristics of frozen cod (Gadus morhua) fillets. Journal of Food Science, 69 (4), 144-152. 
22. U.S. Department of Health and Human Services. (2011). Fish and Fishery Products Hazards and Controls Guidance Fourth Edition. Retrieved March 12, 2019, from https://www.fda.gov/food/seafood-guidancedocuments-regulatory-information/fish-and-fishery-products-hazards-and-controls-guidance-4th-edition.

23. Valtýsdóttir, K., Margeirsson, B., Arason, S., Lauzon, H., \& Martinsdóttir, E. (2010). Guidelines for precooling of fresh fish during processing and choice of packaging with respect to temperature control in cold chains. AVS Fund of Ministry of Fisheries. Iceland. 2.

24. Valtýsdóttir, K., Margeirsson, B., Arason, S., Lauzon, H., \& Martinsdóttir, E. (2011). Thermal modeling of processing and transport of fresh fish. Icelandic Food and Biotech R\&D. 10-11.

25. Waterman, J. (2001). The Cod. FAO in partnership with Support unit for International Fisheries and Aquatic Research. Retrieved March 05, 2019, from http://www.fao.org/3/x5911e/x5911e01.htm\#Chemical\%20 composition.

26. Yerlikaya, P., \& Gokoglu, N. (2010). Effect of Previous Plant Extract Treatment on sensory and Physical Properties of Frozen Bonito (Sarda darda) Fillets. Turkish Journal of Fisheries and Aquatic Sciences, 10(3), 341-349. 